\title{
THE TERRITORIAL MANAGEMENT CONTRACTS AS INNOVATIVE NEW GOVERNANCE OF THE TERRITORY IN THE FRAMEWORK OF THE EUROPEAN UNION CLLD PROGRAMME AND ECOSYSTEM SERVICES POLICY
}

\begin{abstract}
Adriano CIANI, General Secretary of AMAR-WFARA (Associazione Mondiale di Amicizia delle Aree Rurali-World Friendship Association of Rural Areas); Perugia University, Italy, adriano.ciani@unipg.it (corresponding author)

Asta RAUPELIENE, Institute of Business and Rural Development Management, Faculty of Economics and Management, Aleksandras Stulginskis University, Universiteto str. 10, Akademija LT-53361, Kauno raj., Lithuania, asta.raupeliene@asu.lt

Vilma TAMULIENE, Institute of Business and Rural Development Management, Faculty of Economics and Management, Aleksandras Stulginskis University, Universiteto str. 10, Akademija LT-53361, Kauno raj., Lithuania, vilma.tamuliene@asu.lt
\end{abstract}

In the world, the question of the good practice to manage of territory is a pillar of the implementations of Sustainable Development Goals 2015-2030. The authors are working in collaboration with a holistic approach at the topic. In this way, the Smart Communities and Smart Territories are the new paradigms in 21th Century to solve the question of the adaptation at the Climate Change and to guarantee, for the future generation, the conservation and promotion of all potentialities of each territory and identity of areas. Until now, they have use a deductive method to analyse and show, in the framework of the Sustainable Development, the Community Led Local Development (EU Programme for CLLD) and Ecosystem Services, the need to move from an emergency management approach to pre-emptive territory management. The results of this research have produced the original and autonomous configuration of a new and innovative strategy and governance based on a model that puts in synergy the three aspects of the framework that has been given the name of Territorial Management Contracts (TMC). The TMC, appear a possible shared and democratic model that could to combine the territory risk management with solutions of development driving and sharing by the local populations. This innovative approach is strictly linked with the targets of the Sustainable Development Goals 2015-2030 and the Europe 2020 (smart, sustainable and inclusive). The authors argue that the TMC model is now sufficiently mature to pass from the processing phase to that of the implementation that in the Payment of the Ecosystem Services (PES) finds a concrete reinforcement of the scientific analysis carried out.

Keywords: Sustainable development, territory management, ecosystem services, CLLD, smart communities, smart territories.

\section{INTRODUCTION}

The many domestic and international disastrous events, have in the last years and till in the current weeks, proved to us reflect the dramatic situation that is our country but also the prevalence of the areas of all countries. As always, in the face of a disaster, the barrel of politicians and technicians at a different level begins with the citizens who are forced to solve the problems solely by themselves and/or only with the presence of many courageous volunteers.

This further drama repeats the tremendous difficulty with which states never give up illuminating examples (as the New Orleans flood of some years ago in the United States of America) of real-ready emergency response capabilities. The unimaginable capacity of people's reaction (with their own means, with their desperation, with their own sense of the common good, with real application of subsidiarity and bottom-up approach), shows that there are skills in managing emergencies. This highlights that people are primarily capable of preventing and proactive action on the ground, the only real opportunity to limit the catastrophic events.

The financial crisis, which is still struggling with the management of public accounts not only in Italy, but around the world, suggests that the Public Authorities do not have and will not, perhaps for decades, the ability to activate direct intervention policies in the proper and effective management of the territories. It is time then to shift the attention and methods of managing the territory, in the process of slimming the public presence, by counting the self-management capacity of Local Communities. These have always given and give wonderful examples (see all the Italian system of the Territorial Collective Assets which, among other things, affects 1,800,000 hectares, according to the latest Census data in 2010) when it comes to reacting to the emergency but also to the proper prevention.

The territory, at this height, should be considered as a common good, for which the responsibilities of preserving productive capacity, of its physical, historical, cultural, identity and integrity can, with precise rules covering all Common Good (Commons following the winner, Nobel Prize in Economy Elinor Ostrom), be commended to Local Communities

Copyright (C) 2017 The Authors. Published by Aleksandras Stulginskis University. This is an open-access article distributed under the terms of the Creative Commons Attribution License (CC-BY 4.0), which permits unrestricted use, distribution, and reproduction in any medium, provided the original author and source are credited. 
and actors in the area (first of all between them the farmers). The European Union itself is implemented, with the collaboration of the various States of the Union and the various Local Governments, the Development Programs, with various instruments covering the multiplicity of sectors and European society as a whole the period 2014-2020. The Single Strategic Framework emanates the various Funds (ERDF, EAFRD, ESF, etc.), which put the focus of the various strategies on economic mechanisms that encourage active participation (to the objectives of various policies) of citizens and communities, guaranteed to operate with "best practices" for achieving those goals.

This analysis leads directly to the possible use, within this framework, of tools that, through the Mechanisms of Participated Programming, the Public and Private Management Contracts for the approach of Preventing Territory Management.

\section{METHODOLOGY}

The aim is to present, at the agricultural economists and at the policy makers at the National and International levels, a scientific overview of the concrete possible innovative idea of New Governance of Territory suitable for the specificities of Italy but with the vision of the repeatability and transferability in the world.

The method is pertinent at the visionary approach of the research. In fact at this level, there are not still a specific and depress each or experimentation of the proposal. The red line of the paper it's a logical derivation of the larger experience of visits and implementation of Project of Development in many rural areas in the world. It's an analysis arranged in an iterative and interactive process concerning the trend of the territorial situation in many countries. This consequently takes into account, particularly the meteorological events joint at the initiatives to limit their negative effects that inspire, in a certain step of the theoretical phases, the innovative idea of the Territorial Management Contracts TMC's. This idea also was born thanking at the growing role that European Union have assign since starting 2000 years in the Local Communities for the Local Sustainable Development Strategy.

The materials derived from the big data existing for the soil and land management in literature that anyway, as if it have some partial similar aspects of content, in concrete, are two different approach than the meaning of territory. The topic of territory is very new. For the general aspect is represented by some contribute by the French authors and French publications by the public institutions. In French was promoted several years ago the option of Territorial Contract d'Amenagement. The approach in this case, it's not to manage in a bottom-up and subsidiarity way the territory, but the aim of the reference was linked at the participation, at the planning of intervention in the territory, by the Local Community to analyses the alternative use of public finance concerning project development in the areas. For the paper, the authors used the few written elaboration now produced by themselves or jointly, and the ideas from the collaborator of the Research Unit of Applied Economics of Perugia University and joint projects managed by Biosphera Scientific and Cultural Association.

\section{TERRITORY: PAST, PRESENT AND FUTURE}

The past and current time without the proper concept of territory: the mistake of the prevalence use of the word land. The prevalence of the literature in English Language have done, for the past time, very rare sample of research regarding the territory. Until today, continue the use of the word and approach about the land, but we must take into account that there is a very big difference by soil, land and territory.

Soil is the surface layer that covers the earth's crust, resulting from the alteration of a rocky substrate, called the rock, for chemical, physical and biological action practiced by all surface agents and organisms present on it. Soil can

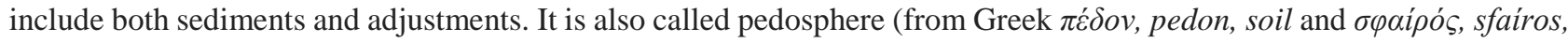
sphere) when considered part of the geosphere.

Land is an Earth Globe, where the life of humans, plants and other animals takes place.

The term, territory derives from the Latino Territorium, which in turn derives the term territory, which means "possessor of the earth". The territory is therefore a defined or delimited area that includes soil or water portions, usually considered as a possession of an animal, a person, an organization or an institution. In biology, an organism defending an area from intrusion (usually by members of its own species) is called territorial. In geography (human geography, see anthropic geography), the territory is a social artifact derived from human processes of territorialization (see territoriality).

However, the territory can be defined in different ways, including three main positions. Following Robert David Sack (1986), the territory is as a reality controlled and modified by companies (includes the idea of "boundary"). One of the main voices about territory prof. Claude Raffestein (1984) substance that the territory as a syntagm determined by the action of the syntagmatic actor. The territory is characterized by the presence of 3 elements (divided into 3 groups) as follows: ecological elements (which can be combined in a different way from the syntagmatic actor: altitude, atmosphere, freshwater basins, coasts, seas / oceans, morphology, soil characteristics, rocks, earthquakes, volcanic activity), biological elements (vegetable cover, fauna), anthropological elements (man and his works).

The author (Ciani A., 2012) has elaborated on updating and more incisive possible definition with which he states "the territory is the physical substrate (soil, cultivable land, water, forests, biodiversity, renewable energies, non-renewable resources, landscapes, buildings, infrastructures, etc.) where economic, social, historical and cultural contents are stratified.

\section{THE CONTENT AND RELEVANCE OF TERRITORY}

The situation in the world, and specifically in many countries, shows a trend of continuous degradation and the use of land for other purposes than agriculture (Coldiretti, 2014). This results both from the inability of local and from national 
governments to cope with the hydrogeological instability, which occurs more and more frequently even in view of the looming effects of a global change in the climate. According to estimates, global damage calculated for 2011 amounted to over 311 billion dollars (IFRC, 2011).

The actions of territorial programming and planning, being innovative activities, must be carried out and strongly supported by an appropriate and widespread use of advanced instrumentation of Information and Communication Technology. The GIS, GPS, DSS and broadband Internet should be the key elements of a "user-friendly" store of knowledge in modern management of the process of the sustainable development strategy. Taking into consideration, the territory is an indispensable way to guarantee the sustainable future of any activity in rural areas.

The territory is an open book written in ink that we cannot normally read (Ciani A., 2012). It is our duty to make it readable to everyone with an innovative, smart and skilled approach. It is because the territory has different roles and functions, as in the following open list: showing and representing, telling stories, speaking, singing, smelling, tasting, stimulating feelings, catalyzing creativity, stimulating inventiveness, attracting, inspiring, intriguing and etc.

The territory in it's the widest and the most holistic form, together with man and with his capacity to analyse, choose and operate together with humanity, which distinguishes him from all other living creatures, should be brought back to the center of strategies used with any development model by using a concrete, operational parameter in order to create the basic conditions for an indefeasible "New Renaissance".

This will focus on the strategies of protection, conservation and enhancement of different areas around the world, the relationship between urban and rural areas, the challenge of renewable energy, green economy and the eradication of poverty. Therefore, these objectives and issues need to be put into practice both in a local, national and international context by professionals who, from the perspective of "global thinking and local acting", have noticeable, modern knowhow and the "ability to act" that matches the ongoing revolution, known as the third and fourth industrial revolution.

In consideration of the above elements, the relevant damages caused by natural disasters and not good practice in the territory management it is necessary to change the approach by counting the self-management skills of local communities, who have always given and give wonderful examples when it comes to emergency response, but also apply correct prevention.

\section{A NEW PARADIGM IN THE 21TH CENTURY - THE SUSTAINABLE MANAGEMENT AND PROMOTION OF TERRITORY TO PROMOTE SUSTAINABLE AGRICULTURE}

The territory in its widest and most holistic form, together with a man with his capacity to analyses, choose and operate together with the "humanity" which distinguishes him from all other living creatures, should be brought back to the center of strategies used by any development model and by using a concrete, operational parameter in order to create the basic conditions for an indefeasible "New Renaissance".

Climate change, jointly at the processes of urbanization continues with the abandonment of many areas with the rural population, agricultural production processes directed towards the large scale, the difficulty of direct intervention in the maintenance of the land by public bodies, could gradually but surely, to reduce the function of "fuel" for the set-up and growth an integrated and sustainable business that is a concrete potential for the implementation of the SDG's 2015-2030.

Above all, they are aware of the strategic prospects of saving the planet through good practice in the processes of the Strategy of Sustainable Development, at the center of which lies the serious global problem of famine and the current phenomena of serious regional food shortages (850 million people live with a daily food calorie level well below the minimum standards, 2 billion live on less than a dollar per day). It is stressed again that after the big financial crisis from 2007 we are in a decreasing capability of the National and Local Government to implement a direct proper strategic plan of the sustainable management of the territory.

The risk in the current time is that the territory could be affected, in relation also at the Climate Change effects, loss suddenly some identity and rare territories as occurred in 2011 in the "Cinque Terre". Other cases could be broken totally and disappeared or the Forest Natural Park as Castel Fusano near Rome, or the Zingaro Natural Park in Sicily destroyed by the fire consequently at the bad maintenance of the areas.

The 21th Century, in this current moment toward the future, left us three very amazing challenges that we can play and for that we must play: the IV Industrial Revolution, the Green and Circular Economy, the 17 SDG's 2015-2030. To participate in a proactive way in this challenge we need to put in practice some new model of the governance for a proper sustainable development in all the territories of the planet.

\section{THE CHALLENGE OF THE TERRITORIAL MANAGEMENT CONTRACTS PROPOSAL}

Motivations. To the farmer or operator in a rural and urban environment that performs concerted actions in the territory, useful for the pursuit of proper preventive management (whose program must be established and participated), the Public Body (State, Region, Province, Consortium, Community) recognizes a quid (direct payment or de-taxation e.g.,) per hectare (or other parameter provided simple, responsive and effective), obviously behind a tight control action. On these principles is based the strong assurance that the Managed Participant through Territorial Contracts can truly guarantee a new season for the country to preserve its territory, to be truly an intelligent, sustainable, inclusive country. The Framework Program and various EU Regulations such as the 1305/2014 for Agriculture and Rural Development, are then a great opportunity to offer a new season to all those who have rooted their life in their own land. They are born with the aims of making every operator in the area a potential active, pre-emptive manager of the same territory who, with 
subsidiarity, can lighten the Public Body by enormous burdens to be used with direct payments and the execution of structural works needed to increase the quality of life of every citizen. On the one hand, it is emphasized that the concept is partly accepted by a part of the country's Scientific Technical Community and many public administrations. It feels like talking about River Contracts, Lake Contracts, Landscape Contracts, Forest Contracts, etc. The approach to territorial management cannot be sectorial and partial, but it must be holistic and systemic, as well as the paradigms of the Sustainable Development Strategy and the complexity that the territory has with its innumerable eco-systemic services.

Targets and Organization. For this aspect, the authors propose the following new instrument of the governance in a holistic approach at the Territory. It is time to significantly change the mode of governing the issue. From an "emergency managed" to an "innovative management and preventive" of the territory with a proactive participation and "bottom up" of those who operate on the same. For example, within the EAFRD - European Fund for Agriculture and Rural Development, in all Regional Rural Development Plans it's recognized direct payments for activities that improves the sustainability as environmental measures, organic farming, etc. The European Union has created the General Framework Agreement for the Actions, but then leaves it to individual countries to propose specific actions on a national level and the Regions at the Regional level. This analysis leads us directly to use as possible, within this framework, tools that provide, through the mechanisms of Participatory Planning, Management Agreements between the Public and Private to apply a preventive territory management. The farmer or the operator in rural and urban environment that performs actions agreed in the territory, useful to the pursuit of proper preventive management (the program must be established and participated), the public body (State, Region, Province, Municipality, Consortium, Community) recognizes a quid (direct payment or tax relief) per hectare (or some other parameter provided simple, responsive and effective), behind obviously tight control action. On these principles underpinning the strong assurance that the Participatory management through Territorial Management Contracts-TMC's can truly guarantee a new era for the country, for the preservation of its territory. The idea is therefore to transform the weakness of every area due to high risk, into an intelligent, inclusive, sustainable, transparent, proactive and concrete opportunity.

A possible model. In theoretical approach the TMC's needs, first of all, to summarize that the implementation of the TMC's needs this following stakes: a model of governance, instruments and supports for the decision making, strategic plan of the TMC, Project Financing and Project Management. The model of governance must be participative by the local population with the involvement of all stakeholders in the ideation, design, project, implementation and monitoring following the iterative and interactive approach.

The proactive involvement of the population in the TMC's must be managed by the economic instruments. They must be based on the principle of the "Willing to Pay or Willing to Accept" as in the framework of the revealed or declared preference of the consumers. Concerning the evaluation, we must consider two different levels. The first one is about the instruments and support they are a pillar to calculate the economic benefits that the single operator produce for the territory and community for his action (taking account, particularly the environmental benefit) and how much and in which modality these benefits will be recognized at the same operator. The second level is the choice, by the Community, the better alternative of the Contract between the Local Community and Public Institutions to implement a proper Project of Territory Management. For the first level the authors suggest the approach of the DPSIR proposed by the EEAEuropean Environment Agency (EEA, 1999).

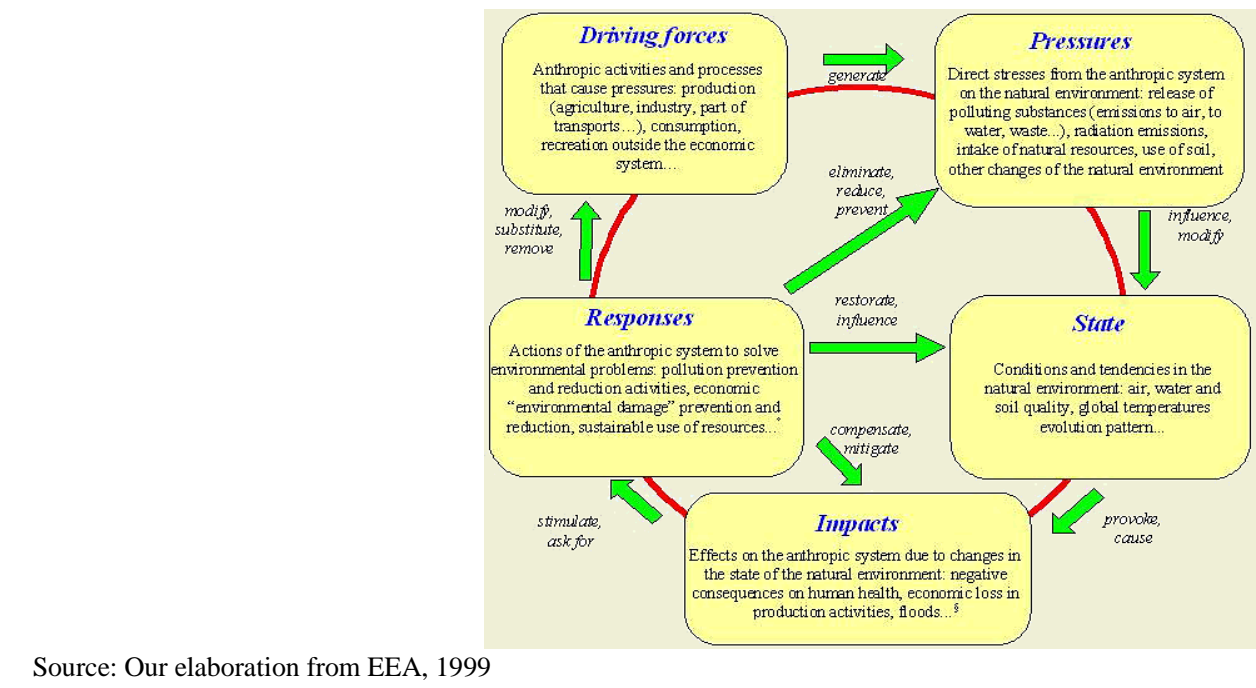

Figure 1. The DPSIR Framework for Reporting on Environmental Issue

The techniques based in the Willing to Pay/Accept that we can use are contingent evaluation or choice experiments. It will be strictly concession with the very big question proposed by the European Union and by the Italian Government about the evaluations of the ecosystem services. (EU Commission 2013; Italian Parliament, 2015).

Concerning the evaluation of the alternative of solutions of the type of contract could be suitable the approach of Multi-Criteria Analysis Aid Decision - MCAAD with which all the all objective problems in the preparation, implementation and monitoring of the TMC are at the solution level. Concerning the strategic plan, it's an ideal start, 
especially as ideation by the local stakeholders. After this phase will run the preparation of the Plan jointly with negotiation between the territorial higher-level government levels and the TMC organization of the Local Communities.

Of course, all this must be coupled by Project Financing that must respect the criteria who make when between all the subjects involved as singles, private or public bodies.

The Financial Management must have a clear position and will be when it's possible the only Committee Board of the Organization of the TMC. The implementation of a TMC it's a concrete way to put at the center of the Sustainable Development Strategy the Local Population that with the with a generalized dissemination policy of a friendly use of ICT becomes concrete in Smart Community contributing to the validation of the Smart Territory and that means a Territory progressed and happy.

\section{DICUSSION AND OPEN QUESTIONS}

The paper proposes a new logical possible instrument of New Governor of the Territory and achieve the concrete model to apply in a concrete way. The option of the Territorial Management Contracts appear a new possible paradigm that combines the question of the limitation of the worsening of the loss of the territory that as for the consume of the soil for artificial destination as for the erosion, landslides, flooding, and other event as fire or different kind of pollution and the request of the strategy to assign the sustainable development strategy at the local communities. Anyway, we are only at the first step of the proposal also if the author in the last year has some first requests to set - up a possible experimental pilot project. In Sardinia Regionit's established a contact with the Qedora Association for the project "S'ortu de Tziviriu", which provides for the rehabilitation of a degraded urban area in the municipality of S. Gavino Monreale through an action of active citizenship. In Calabria Region it's very recently established a first contact to help the Basso Ionio Community Association concerning the future management of the Nika River Valley in relation particularly at the possible enlargement of the landfill of Scala Coeli. In Umbria the authors have participated in the preparation of the Atlas of the Landscape Contracts and have proposed a Territorial Management Contract of the Martani Mountains where there are 6 Territorial Collective Asset to engage in a coordinate project of Local Development under the joint Local Communities.

The open question is the biggest confusion, also in a lexical point of view, because there are many initiatives that born with different kind of names of contracts as rivers, lakes, landscapes, forests, etc. The authors disagree strongly this situation because there is the risk that in the territory where we need to unify and sharing solutions the creation in the same area more than one Contract, we added more division and conflicts of interest that without any initiatives. It is also believed that language and the lexicon in a foundation phase have their role. The Territorial Management Contracts is the General Contract/ General Program (Umbrella Framework of References) for the Protection by the Local Community the Territory within which the various aspects (rivers, lakes, landscapes, forests, etc.) can and must be located. If this is not the case, we will soon be in a position to launch, especially in the most innovative ways of innovation, such a set of contract hypothesis that will only lead to conflicts between the various sectors / contracts. This is a General Contract General Program (Umbrella Contract) for the Protection of a Local and Community Territory within which the various aspects (rivers, lakes, landscapes, forests, etc.) can and must be located.

\section{CONCLUSIONS}

The territory at this height must be considered a common good for which the responsibility of preserving the productive capacity of their physical, historical, cultural, identity integrity can, be referred to the Local Communities (first of all farmers). It is the way and it's time to capture the New Paradigms and New Approaches that the Territory has to offer. Among the New Paradigms we can include, in addition to the four related at the Sustainable Development strategy, those as following:

- territory is a living entity consequently at the vision as book to be able to read;

- territory is the reservoir of resources to be put into the cycle of a sustainable production system of goods and ecosystem services;

- territory is an intelligent cognitive system that educates and learning with a smart use of the ICT;

- territory is specificity, rarity and specialty but social inclusive;

- territory is "TRADI-OVATION" (intended as an acronym for "Territory, Rural Areas, through Development, Innovation, Organization, Valorization, user friendly Technology, ICT sharing, Online Networking). (Ciani, 2012). In this sense is the key word and the main theme around which any innovative process can be structured to give effective credibility and to erase the increasing disillusion that follows major international meetings, in order to move from words to actions and create the foundations for the New Model of Management and Promotion of the Rural Areas.

- territory send us the option to Overcoming of the Labour Systemic Prison by the Free Time and the Recovering of the Environmental Space.

As everyone knows, the European Union itself in 2014 began a process to develop, with the cooperation of the various States of the Union and of the various Local Governments, Development Programs, as a whole, for the period 2014-2020. This analysis leads us directly to use as possible, within this framework, tools that provide, through the mechanisms of Participatory Planning, Management Agreements between the Public and the Private to the preventive management of the territory. 
On these principles underpinning the strong assurance that the Territorial Management Contracts can truly guarantee a new season at the Country for a preservation of its territory, to be a fundamental part of people improvement the economic, environmental and social status.

Territorial Management Contracts it's a Proposal with a vision of the General Contract /General Program between the Local Communities and Public Administrations within which the various aspects (rivers, lakes, landscapes, forests, etc.) can and must be taking into account. If this is not the case, we will soon be in a position to launch, especially in the most innovative ways of innovation, such a set of contract hypothesis that will only lead to conflicts between the various sectors/contracts.

The model of organization, evaluation of benefits to assign at the participant of the action and the choice of the better alternative of TMC's, from the theoretical point of view, in the paper has achieved strong and solid inductive and deductive consistency. Some concrete cases, in different regions, appear suitable to implement possible experimental Pilot Projects. The idea of TMC's is therefore to transform the weakness of every area due to high risk, into an intelligent, inclusive, sustainable, transparent, proactive, concrete opportunity. To achieve in all rural areas of the world the character of Smart Communities and Smart Territory.

\section{REFERENCES}

1. Ciani, A. 2012. The Sustainable Management and Promotion of Territory: A strategic Operative Education Plan and Training as a Result of Collaboration Between Perugia University. Todi's State Technical Agricultural College and the Local Municipality, in Sustainable Development at Universities: New Horizons, Peter Lang Editor.

2. Ciani, A., Paolotti, L. and Rocchi, L. 2012. The territorial management contracts (TMC): a practical tool to reduce the risk in land resource management and to improve the multi-functionality of agriculture. $126^{\text {th }}$ EAAE Seminar, New challenges for EU agricultural sector and rural areas. Which role for public policy? Capri (Italy), June 27-29, 2012, Perugia, Italy

3. Ciani A. 2015. The Charter of Todi and the StrategyofEducation for a SustainableManagement and PromotionofTerritory. Springer International Publishing Switzerland 2015W. LealFilho et al. (eds.), Implementing Campus GreeningInitiatives, WorldSustainability Series.

4. Ciani A., Fagioli, F.F. 2015. Territory: A Living Book To Be Able To Read Which Inspires and Contaminates Feelings of Wellbeing. Florence "Sustainability of Well-being" International Forum 2015: "Food for sustainability and not just food " Florence SWIF 2015, 4-6 June 2015, Agriculture and Agricultural Sciences Procedia, pp. 339-335.

5. E.U. Commission, Community 2014. Led Local Development, Cohesion Policy 2014-2020, Factsheets. Available at: http://ec.europa.eu/regional_policy/sources/docgener/informat/2014/community_en.pdf .

6. E.U. Commission 2013. Mapping and Assessment of Ecosystems and Their Services. Technical Report.

7. E.U. Commission 2015. Closing the loop. An EU action plan for the Circular Economy, COM (2015) 614, Bruxelles.

8. E.U. Commission 2010. Europe 2020: A strategy for smart, sustainable and inclusive growth, COM(2010) 2020 final., http://eurlex.europa.eu/LexUriServ/LexUriServ.do?uri=COM:2010:2020:FIN:EN:PDF

9. E.U. Commission. 2012. Smart Cities and Communities - European Innovation partnership. Communication from the Commissione, Brussels, 10.7.2012, C(2012) 4701 final.

10. Francis, P. 2015. Encyclical Letter "Laudatosi" on the holy Father Francis on care for our Common Home. Libreria Editrice Vaticana, Vatican City, Rome.

11. Italian Parliament 2015. National Law n. 221 of 28 December 2015,Environmental Annexed ,G.U. 13 of 18 January 2016.

12. Ostrom, E., Schroeder L., Wynne S. 1993. Institutional Incentives and Sustainable Development: Infrastructure Policies in Perspective. Oxford: Westview Press, 1993.

13. Raffestein, J.C. 1984. Territoriality - A Reflection of the DiscrepanciesBetween the Organization of Space and Individual Liberty. International Political Science Review, Vol. 5, No. 2, pp. 139-146. https://doi.org/10.1177/019251218400500205

14. Sachs, J. 2015. The Age of Sustainable Development. Columbia University Press, New York, p. 543.

15. Sack, R.D. 1986. Human Territoriality: its theory and history. Cambridge University Press, Cambridge.

16. UNGASS-United Nation General Assembly 2015. Transforming Our World: the Agenda 2030 for Sustainable Development. New York, A/RES/70/1.

17. Webster, K. 2015. The Circular Economy: A Wealth of Flows. Ellen Macarthur Foundation Publishing, New York. 